\title{
Ekonomi Politik Akses atas Lahan: Kontestasi atas "Negara" dalam Mega Proyek Merauke Integrated Food and Energy Estate (MIFEE)
}

\section{Tadzkia Nurshafira ${ }^{1}$}

\begin{abstract}
Abstrak
Artikel ini menganalisis prakondisi struktural dan diskursif yang menghambat dan/atau memungkinkan berbagai aktor mengakses-mendapatkan, mengontrol, dan mempertahankan -aliran keuntungan dari proyek MIFEE. Dengan menggunakan perspektif akses Ribot dan Peluso (2003) dan selektivitas strategis negara Jessop (1999), tulisan ini berargumen bahwa upaya untuk mendapatkan aliran keuntungan MIFEE di saat yang sama juga merupakan upaya untuk memperebutkan "negara"; atau untuk melakukan balance of power (keseimbangan kekuatan) yang kemudian terkondensasi menjadi sebuah selektivitas struktur dan memengaruhi strategi para aktor. Artikel ini mengadopsi perspektif yang spesifik terkait negara, bukan sebagai aktor otonom melainkan sebagai sebuah ruang kontestasi politik yang merupakan produk dari pertentangan dan relasi kuasa antara berbagai kelompok sosial di masyarakat. Dengan melihat negara sebagai struktur, tulisan ini menekankan dimensi agensi politik para aktor, terutama masyarakat lokal yang berupaya mentransformasi struktur tersebut agar memungkinkan mereka untuk mendapatkan akses yang berkelanjutan atas lahan dalam MIFEE. Analisis terkait akses ini mengkritik kajian yang bersifat esensialistik terkait negara kapitalis (capitalist state), dimana negara diasumsikan sebagai entitas homogen, statis, dan hanya alat perpanjangan tangan kapital untuk akumulasi profit. Padahal, negara adalah produk dari relasi antara struktur dan agensi: ia memiliki struktur dan logikanya sendiri yang selalu berubah seiring dengan kontestasi antara berbagai kekuatan sosial yang berupaya memperebutkan dan mendefinisikan negara.
\end{abstract}

Kata kunci: MIFEE; Akses; Negara

1 Program Manager Citizen Engagement and Natural Resource Governance Education (CitRes-Edu), Departemen Politik dan Pemerintahan, Fakultas Ilmu Sosial dan Ilmu Politik, Universitas Gadjah Mada. 


\section{PENDAHULUAN}

Tulisan ini berupaya menjelaskan mega proyek Merauke Integrated Food and Energy Estate (MIFEE) dengan perspektif akses ala Ribot dan Peluso (2003), serta menggabungkannya dengan analisis selektivitas strategis negara (Jessop, 1999) yang menjelaskan peran signifikan dari negara sebagai sebuah struktur, serta menggarisbawahi karakter relasional dari dualisme struktur agensi dalam upaya mendapatkan/ mempertahankan akses tersebut. Dengan menggunakan kerangka akses, tulisan ini berupaya memahami prakondisi struktural dan diskursif yang menghambat dan/atau memungkinkan berbagai aktor mengakses-mendapatkan, mengontrol, dan mempertahankan-aliran keuntungan dari proyek MIFEE yang diresmikan oleh Susilo Bambang Yudhoyono pada tahun 2010. Di saat yang sama, prakondisi struktural dan diskursif tersebut terbentuk dari, dan juga membentuk, "selektivitas strategis" yang dimiliki oleh negara. Analisis terhadap negara menjadi penting karena berdasarkan kajian-kajian terkait MIFEE, negara sering kali muncul melalui cara pandang strukturasionis sebagai entitas atau kesatuan struktural yang utuh, definitif, dan netral (Giddens, 1984). Negara juga sering dianggap sebagai suatu entitas struktural dan powerful yang dapat secara otonom mengambil pilihan kebijakan. Konsep negara ini memisahkan aspek relasional antara struktur dan agensi yang membentuk dan dibentuk oleh negara (Jones, 2007; Jessop, 1990). Karenanya, negara tidak dapat ditempatkan sebagai struktur yang terpisah dan berada "di atas" segala aksi, strategi, dan kebutuhan dari berbagai kelompok sosial yang bekerja di dalamnya: negara adalah reproduksi mutual antara struktur dan agensi yang saling memengaruhi dan membentuknya (Hay et.al., 2006). Dalam arti lain, negara memiliki struktur dan logikanya sendiri yang terus berubah seiring dengan kontestasi atas negara dalam konteks spasial dan temporal yang berbeda. Hal ini membuatnya signifikan dalam mengontrol dan mendistribusikan-atau tidak mendistribusikan- 
keuntungan atas sumber daya alam kepada berbagai aktor dalam proyek MIFEE, karena kontrol akses atas sumber daya dapat dibaca sebagai bekerjanya struktur selektivitas negara dan menjadi bagian dari upaya negara mengonsolidasikan kekuasaannya. Dalam upaya tersebut, struktur selektivitas negara juga secara terus-menerus diubah oleh konfigurasi aktor yang mengambil pilihan-pilihan dalam konteks strategis yang berbeda-beda.

Tulisan ini berargumen bahwa upaya untuk mendapatkan aliran keuntungan dari sumber daya alam dan lahan melalui MIFEE di saat yang sama juga merupakan upaya untuk memperebutkan "negara". Upaya tersebut dipengaruhi oleh mekanisme akses tertentu dengan mekanisme yang dipahami sebagai konfigurasi dari cara, relasi, dan proses yang memungkinkan atau tidak memungkinkan aktor untuk mendapatkan keuntungan dari MIFEE (Ribot dan Peluso, 2003). Bekerjanya mekanisme tersebut dipengaruhi oleh posisi tiap aktor yang berbeda-beda dalam struktur ekonomi-politik tertentu, serta dalam konteks spasial-temporal yang berbeda. Hal ini yang kemudian membuat kontestasi untuk mendapatkan akses dalam proyek MIFEE menjadi relasional: ia tidak pernah stabil dan selalu berubah dari waktu ke waktu. Pada titik terjauhnya, akses yang dimiliki oleh berbagai aktor dalam MIFEE juga dipengaruhi oleh, salah satunya, struktur relasi kuasa yang terkondensasi di level nasional dan lokal sejak era Pasca Kemerdekaan Indonesia. Karenanya, tulisan ini melihat logika yang bekerja di balik MIFEE dan sekaligus berperan sebagai struktur yang membatasi kemungkinan masyarakat lokal mendapatkan akses atas lahan yang berkelanjutan dalam MIFEE. Logika tersebut adalah produk dari selektivitas strategis negara yang memungkinkan suatu narasi hegemonik terkait pembangunan diwujudkan melalui MIFEE. Logika yang hegemonik ini memengaruhi akses masyarakat terhadap lahan dan membatasi pilihan-pilihan yang diambil masyarakat untuk merespons keterbatasan akses tersebut. 
Meski demikian, tulisan ini juga menekankan aspek agensi dari masyarakat dalam mengubah struktur selektivitas yang hegemonik dalam MIFEE. Masyarakat berupaya secara terus-menerus mengubah struktur tersebut-baik melalui penentangan, upaya kooptasi atau instrumentalisasi-agar struktur tersebut bisa bekerja sesuai kepentingan mereka dan juga mendapatkan akses terhadap lahan dalam MIFEE. Upaya masyarakat ini kemudian didefinisikan sebagai upaya untuk merebut "negara" atau upaya untuk mengubah struktur selektivitas negara yang memberi ruang bagi mereka untuk mendapatkan manfaat dari proyek MIFEE.

Tulisan ini menggunakan metode analisis literatur yang membahas pertentangan lahan masyarakat dalam MIFEE. Tulisan ini menggunakan data-data sekunder dari berbagai berita daring, dokumen resmi pemerintah, serta laporan penelitian dan investigasi oleh berbagai aktor yang mencakup pemaparan data-data dari aktoraktor di lapangan.

\section{AKSES DAN SELEKTIVITAS NEGARA: ULASAN DAN PENDEKATAN}

Berbagai literatur telah berupaya memahami aspek spesifik dari MIFEE melalui berbagai cara. Tulisan ini melakukan ulasan terhadap literatur yang menganalisis sosial-politik terhadap MIFEE. Artikelartikel tersebut memiliki cara pandang yang spesifik terkait konflik yang terjadi di sekitar implementasi MIFEE dan juga terkait "negara". Artikel tersebut kemudian dikategorisasi menjadi tiga berdasarkan bagaimana mereka membaca dan memahami penyebab dari konflik yang terjadi dalam MIFEE.

Pertama, beberapa artikel melihat konflikyang terjadi dalam MIFEE disebabkan oleh upaya negara untuk merampas dan mengapropriasi lahan masyarakat beserta cara yang diambil negara. Karenanya, 
konflik dicirikan dengan upaya masyarakat melakukan perlawanan terhadap negara. Artikel Pichler (2015) secara spesifik membahas hal ini. Ia berupaya melihat peran negara dalam mengapropriasi dan mengontrol lahan di Indonesia melalui produksi perkebunan sawit dan agrofuel; bahwa negara memiliki strategi legal yang mendukung proyek hegemoni agro industri dalam MIFEE. Artikel ini melihat mekanisme marginalisasi dan privilese yang terjadi melalui selektivitas struktural, strategi, dan spasial yang muncul dalam strategi negara, yang secara spesifik merujuk pada diskursus "legal". Temuannya adalah bahwa strategi ini berhasil menjadi hegemoni yang mengintegrasikan kepentingan partikular kelompok subaltern dalam kepentingan dominan yang tampak universal.

Zakaria et. al. (2011) lebih jauh berupaya memetakan permasalahan MIFEE yang berkembang di level lokal. Tulisan mereka menjelaskan perlawanan masyarakat terhadap dinamika investasi dengan kebutuhan lahan yang sangat besar dalam MIFEE dan bahwa MIFEE berpotensi membawa dampak yang tidak kecil. Tulisan ini memahami neoliberalisme dalam kekuasaan negara yang sangat besar dan bahwa neoliberalisme adalah agenda konsolidasi kelas yang berkuasa. Tulisantulisan ini menempatkan aktor sebagai suatu kesatuan utuh yang seolah-olah dapat memutuskan secara rasional untuk "merampas" dan mengambil lahan masyarakat.

Silibun dan Putri (2018) berupaya melihat dampak lingkungan dari implementasi MIFEE melalui perspektif legal empiris, terutama efektivitas dari hukum dan bagaimana hukum tersebut beroperasi dalam masyarakat. Mereka melihat bahwa proyek MIFEE mengancam eksistensi dari hak-hak komunitas, dimana perusahaan-perusahaan besar berperan signifikan dalam mengonversi lahan masyarakat menjadi pertanian berskala masif. Artikel Wambrauw dan Morgan (2017) juga memiliki posisi serupa dengan argumen bahwa MIFEE memiliki dampak yang berbeda-beda pada berbagai pemangku 
kepentingan, namun masyarakat adat Marind-Anim menjadi pihak yang paling dirugikan karena lahan mereka yang direbut oleh negara. Dewi (2016) juga menegaskan bahwa konflik terjadi karena adanya perampasan lahan yang dilakukan negara melalui pemetaan formal yang mendukung pengakuan legal atas lahan masyarakat untuk digunakan dalam MIFEE.

Kedua, beberapa artikel melihat konflik MIFEE disebabkan oleh kegagalan negara menjalankan kewajibannya terhadap masyarakat dan memenuhi hak warga negara. Suryani (2016) fokus pada kekerasan struktural yang melekat dalam kebijakan MIFEE menggunakan Galtung (1969). Kebijakan ini dianggap melanggar hak asasi manusia dalam operasionalisasi MIFEE. Artikel ini melihat bahwa negara sebagai entitas yang memiliki kekuasaan besar, membatasi pilihanpilihan yang diambil oleh entitas dengan kekuasaan yang lebih kecil dan pada akhirnya dapat menyebabkan pelanggaran hak asasi manusia. Pelanggaran tersebut merupakan konsekuensi dari aksi dan kebijakan pemerintah, serta merupakan produk dari kegagalan negara dalam memenuhi kewajibannya dan hak warga negara. Mustika (2014) melihat bahwa negara seharusnya menjadi aktor utama yang dapat menjamin hak atas masyarakat dalam MIFEE dan seharusnya tidak berpihak pada pemilik kapital yang besar. Ia pada dasarnya fokus pada konsekuensi dari MIFEE; bahwa ada yang kalah dan menang. Secara garis besar, MIFEE memberikan dampak negatif yang sangat besar bagi penghidupan dan kesempatan masyarakat lokal untuk bertahan hidup. Bolin (2011) memiliki posisi serupa dengan argumen bahwa MIFEE merepresentasikan lemahnya upaya aparatur negara dalam menjamin hak masyarakat adat dan menghasilkan pelanggaran atas hak-hak tersebut.

Ketiga, beberapa artikel berupaya melihat konflik MIFEE sebagai permasalahan teknis. Dalam arti lain, kebijakan MIFEE dianggap sudah baik, namun implementasi praktiknya perlu diperbaiki. Artikel-artikel 
ini fokus pada berbagai rekomendasi untuk membuat MIFEE lebih efektif. Karenanya, Irba Djaja et. al. (2018) berupaya memformulasikan strategi yang efektif, ramah lingkungan, dan berkelanjutan dalam mengembangkan Farming Production Centre (KSPP) MIFEE di Merauke. Obidzinski et. al. (2013) berupaya memberikan rekomendasi pada pemerintah untuk mengambil pendekatan yang terukur atas MIFEE. Pada dasarnya, mereka menjelaskan dampak dari akuisisi lahan berskala besar yang terjadi dalam MIFEE dan potensinya untuk memenuhi persyaratan sustainability yang ditentukan oleh RSPO, ISPO, dan FSC. Mereka menempatkan pemerintah sebagai representasi dari negara menjadi sebuah aktor yang dianggap bertujuan mempromosikan MIFEE sebagai langkah strategis untuk menjamin keamanan pangan dan energi juga untuk meningkatkan pertumbuhan ekonomi Indonesia. Karenanya, MIFEE harus diperbaiki dengan memberikan bentuk evaluasi yang lebih terukur agar dapat mencapai tujuan awalnya.

Pada dasarnya, Lamonge (2012) memberikan argumen yang cukup kompleks terkait MIFEE. Hal ini tampak melalui upayanya membaca agenda neoliberalisme dalam globalisasi yang membentuk strategi pembangunan Indonesia melalui MIFEE dan memengaruhi relasi kuasa dan sosial di antara pemerintah pusat dan lokal, masyarakat adat, dan sektor privat. Artikel ini juga menganalisis kebijakan tata kelola di Papua untuk melihat relasi kuasa yang asimetris dan menjelaskan relasi sosial, politik, dan ekonomi di wilayah tersebut. Meski demikian, karena menyejajarkan paradigma neoliberal dengan kebijakan pemerintah, artikel ini menempatkan negara sebagai satu entitas yang utuh dan berperan hanya sebagai aktor yang mengeluarkan berbagai kebijakan.

Artikel-artikel yang sudah ada menganalisis MIFEE dengan cukup komprehensif, namun memiliki beberapa kelemahan. Artikel-artikel tersebut fokus memahami implikasi atau dampak dari MIFEE bagi masyarakat dan lingkungan, serta melakukan penilaian apakah dampak 
tersebut baik atau buruk bagi komunitas. Tetapi, artikel yang ada luput membahas negara sebagai sebuah ruang. Kebanyakan menempatkan negara hanya sebagai salah satu aktor yang kemudian direpresentasikan oleh pemerintah dan berkontestasi dengan aktor-aktor lain. Artikelartikel tersebut menempatkan negara sebagai suatu kesatuan utuh yang dapat dinilai dari keputusan yang diambil oleh pemerintah, dan hal ini mereduksi kompleksitas konflik yang ada karena analisis hanya dilakukan pada konflik antara "negara" beserta aliansi bisnisnya, versus komunitas. Simplifikasi ini gagal untuk melihat dinamika di lapangan, dimana aliansi aktor sangat tumpang tindih; bahwa pemerintah berbeda dari "negara" dan tidak selalu merepresentasikannya karena banyak konflik yang terjadi di antara pemerintah itu sendiri. Akibatnya, artikelartikel ini melihat bahwa pada satu titik, masyarakat harus dipisahkan dari negara karena negara adalah suatu entitas yang harus mereka lawan dan bukan menjadi bagian dari mereka. Artikel ini gagal untuk melihat hubungan relasional antara negara dan berbagai aktor lain, dimana keputusan dan strategi yang diambil oleh aktor membentuk negara dan di saat yang sama, negara juga dapat membentuk atau memengaruhi strategi yang diambil oleh aktor tersebut.

Oleh karena itu, artikel ini membaca dan memahami MIFEE sebagai konflik antara berbagai aktor dalam memperebutkan negara. Konflik ini terjadi karena berbagai agensi pemerintah, beserta aktoraktor lain seperti perusahaan, NGO, masyarakat lokal imigran, atau masyarakat adat berupaya untuk merebut dan menggunakan struktur selektivitas negara demi mewujudkan kepentingan mereka. Dalam arti lain, para aktor bertarung untuk mendapatkan privilese dari negara sebagai sebuah struktur dan enggan untuk kemudian dieksklusi darinya. Hal ini yang membuat banyak aktor berupaya mengubah struktur selektivitas negara yang memberikan dan tidak memberikan privilese pada cara pandang atau praktik tertentu. 
Tulisan ini menggunakan perspektif akses ala Ribot dan Peluso (2003) dan selektivitas struktural negara ala Jessop (1999) untuk menjelaskan kontestasi aktor dalam mendapatkan keuntungan dari MIFEE. Akses dianggap bukan sebagai hak, namun sebagai kemampuan (ability) untuk mendapatkan keuntungan dari sesuatu. Cara pandang ini mengkritik gagasan "properti" yang menekankan pada hak untuk mengklaim keuntungan dari sesuatu. Akses bukan sekadar hak dengan terminologi hak diasosiasikan sebagai kekuatan legalitas dan formal. Akses melampaui yang formal dan informal, legal dan ilegal-ia mencakup berbagai cara apa pun yang memungkinkan seseorang atau sekelompok orang mendapatkan keuntungan dari sesuatu.

Aspek ekonomi politik dari akses dapat dilihat ketika pemahamannya dibagi menjadi dua, yakni kontrol terhadap akses dan upaya mempertahankan akses. Dalam arti lain, terdapat kontestasi dan relasi kuasa antar-aktor yang berupaya mendapatkan kontrol atas akses keuntungan tersebut dan dalam mempertahankan akses yang telah ia miliki. Analisis terhadap akses dilakukan melalui tiga tahap. Pertama, mengidentifikasi dan memetakan aliran keuntungan yang kemudian diperebutkan. Dalam arti lain, berbagai aktor menelaah keuntungan akses. Kedua, mengidentifikasi mekanisme yang digunakan oleh berbagai aktor untuk mendapatkan, mengontrol, dan mempertahankan akses atau aliran keuntungan yang diperoleh. Ketiga, menganalisis relasi kuasa di balik mekanisme akses dari aktor tersebut.

Analisis akses tersebut kemudian digabungkan dengan analisis terhadap struktur selektivitas strategis negara. Hal ini menjadi penting karena struktur selektivitas tersebut memengaruhi dan membentuk atau menghambat kesempatan berbagai aktor yang berbeda dalam mendapatkan akses terhadap keuntungan dari MIFEE. Jessop mengambil konseptualisasi negara ala Poulantzas yang menekankan bahwa negara memiliki otonomi relatifnya; ia bukan sebuah instrumen yang dapat diakses secara merata oleh seluruh kelompok sosial dan 
dapat digunakan untuk tujuan apa pun, dan bukan juga subjek rasional yang bisa melakukan kalkulasi dengan asumsi bahwa dirinya utuh dan memiliki tujuan yang jelas (Jessop, 1999).

Negara di sini didefinisikan bukan sebagai aktor atau entitas yang homogen melainkan negara adalah relasi sosial dan strategic field-ruang politik dan kontestasi yang merupakan produk dari keseimbangan kekuatan antara berbagai kelompok sosial di masyarakat. Negara bukan sebuah entitas, namun merupakan relasi sosial yang memiliki berbagai efek berbeda pada pilihan strategi aktor di dalamnya. Karenanya, negara bukan sebuah kesatuan entitas yang tetap dan utuh, bukan sebuah lembaga atau "koordinator" yang bersifat netral atas berbagai kepentingan sosial masyarakat, dan bukan sebagai perpanjangan tangan dari kepentingan borjuis kapitalis. Sebaliknya, negara didefinisikan dan ditentukan oleh relasi sosial yang lebih besar. Praktik dan efektivitas dari kekuasaan negara akan bersifat kontinjen, sesuai dengan kondensasi material yang terjadi dari kontestasi dan keseimbangan kekuatan antara berbagai kelompok sosial tersebut. Kekuasaan negara dihasilkan dari interaksi terus-menerus dan relasional antara (1) selektivitas strategis negara yang bersifat struktural dari negara sebagai sebuah "institutional ensemble" dan (2) berbagai kekuatan sosial yang beroperasi di dalam, sekaligus berjarak dari, negara itu sendiri dan berupaya untuk mentransformasinya.

Meski negara memiliki struktur seletivitasnya, analisis terhadap negara mengharuskan adanya pembacaan terhadap aspek relasional antara struktur dan agensi. Analisis tersebut harus mencakup identifikasi atas berbagai strategi politik yang spesifik yang dilakukan oleh aktor yang berbeda-beda, karena negara merupakan sebuah situs strategis dari berbagai aksi politik. Aktor-aktor tersebut memiliki identitas dan kepentingan spesifik dalam konteks spasial-temporal tertentu. Mereka berupaya memenangkan kepentingannya dari berbagai kepentingan kelompok sosial lain dengan menggunakan berbagai strategi. Di titik 
ini, konfigurasi negara pada suatu konteks memberikan privilese akses pada suatu kelompok, strategi, identitas, konteks spasial-temporal, koalisi diskursus, dan/atau kepentingan tertentu. Dalam arti lain, dengan kontestasi jejaring kekuasaan yang kompleks dan karakter koersifnya, negara muncul sebagai sebuah entitas yang secara struktural memberikan privilese bagi, atau "memilih", manuver politik-aktor, diskursus, identitas, strategi, pendekatan-tertentu (Jessop, 1985) dalam memahami MIFEE. Struktur ini yang kemudian disebut sebagai selektivitas strategis dari negara. Perubahan dari berbagai dimensi tersebut menghasilkan outcome konfigurasi negara yang berbeda dan memberikan implikasi pada upaya aktor untuk mewujudkan kepentingannya (Jessop, 1999).

Perlu digarisbawahi bahwa Jessop (1999) memberikan suatu pendekatan yang dapat melengkapi Ribot dan Peluso (2003) terkait signifikansi dari agensi. Meskipun pada dasarnya kajian akses ala Ribot dan Peluso (2003) memberi ruang bagi agensi yang lebih besar pada kelompok-kelompok marginal dalam upayanya mendapatkan/ mempertahankan aksesnya, Jessop (1999) menjelaskan bagaimana agensi tersebut bekerja di tengah keterbatasan posisi aktor dalam struktur hegemonik negara, untuk mengakali struktur tersebut. Bagi Jessop (1999), aktor-aktor yang terlibat dalam MIFEE, termasuk yang marginal, memiliki kemampuan berbeda-beda untuk memahami struktur yang mendorong atau menghambat aksesnya terhadap sumber daya. Dengan pemahaman tersebut, aktor dapat merespons atau mengambil tindakan yang strategis agar upayanya tetap dianggap relevan bagi, atau dapat "dibaca" oleh, struktur dominan negara. Dengan begitu, mereka dapat "mengakali” struktur yang bekerja untuk mempertahankan aliran keuntungan dari MIFEE, bahkan mengubah struktur tersebut.

Analisis dibagi menjadi tiga tahap (Ribot dan Peluso, 2003) yang saling berkaitan dan sudah dijelaskan di atas. Pertama, mengidentifikasi 
dan memetakan sumber daya yang diperebutkan dan aliran keuntungan yang aktor-aktor dapatkan dari MIFEE. Kedua, memetakan berbagai mekanisme yang memungkinkan atau menghambat suatu aktor untuk mendapatkan, mengontrol, dan mempertahankan keuntungan yang didapatkan dari MIFFE. Analisis terhadap mekanisme ini mencakup pembacaan terkait selektivitas strategis negara yang membuat pemerintah dan investor memiliki akses yang besar pada lahan di Merauke, sedangkan masyarakat adat harus mendapat porsi kecil atau tidak sama sekali. Ketiga, menelaah relasi kuasa yang bekerja di balik mekanisme akses dan selektivitas strategis negara tersebut. Relasi ini dipengaruhi oleh perbedaan posisi aktor yang berubah-ubah dalam struktur ekonomi-politik proyek MIFEE. Hal ini juga yang kemudian memberikan ruang bagi manuver-manuver yang dilakukan oleh aktoraktor marginal untuk mengakali struktur selektivitas negara dan tetap mendapatkan keuntungan dari proyek MIFEE.

\section{ALIRAN KEUNTUNGAN DAN KONFLIK ATAS LAHAN DALAM MIFEE: AKUMULASI PROFIT VS EKONOMI SUBSISTENSI}

Bagian ini membahas sumber daya yang menjadi basis dari aliran keuntungan yang diperebutkan dalam MIFEE. Sumber daya inilah yang menjadi pintu masuk dalam kajian akses: aktor-aktor dalam proyek MIFEE berupaya untuk mengontrol dan mempertahankan keuntungan yang mereka dapatkan dari sumber daya tersebut. Pada mega proyek MIFEE, sumber daya yang dimaksud adalah lahan.

Secara garis besar, terdapat dua temuan penting terkait hal tersebut. Pertama, lahan memiliki posisi yang sangat sentral dalam proyek MIFEE. Penggarapan atau komodifikasi atas lahan memberikan suatu nilai tambah yang kemudian berupaya didapatkan dan dipertahankan oleh aktor-aktor dalam MIFEE. Karenanya, MIFEE pada dasarnya 
dapat dipahami sebagai sebuah konflik atas lahan. Kedua, lahan dipahami secara berbeda dan digunakan untuk tujuan yang beragam oleh aktor-aktor dalam MIFEE. Selain dipahami sebagai komoditas yang dapat diperjualbelikan oleh sebagian aktor, lahan juga dipahami sebagai sumber identitas, penghidupan, simbol kemandirian, atau relasi dengan leluhur bagi sebagian lainnya.

Melalui akuisisi dan penggarapan lahan, berbagai aktor mendapatkan keuntungan. Pada dasarnya, aktor yang terlibat dalam MIFEE dapat dikategorikan menjadi empat: sektor publik, sektor privat, masyarakat sipil (nasional dan internasional), dan masyarakat lokal (Lamonge, 2012). Meski demikian, cara pandang dan pemaknaan atas lahan-serta keuntungan yang berusaha didapatkan darinya-yang bekerja dalam empat kategori aktor tersebut dapat dikelompokkan menjadi dua bentuk.

Pertama, bagi pemerintah pusat dan lokal, lahan dianggap sebagai sebuah komoditas yang bernilai dan memiliki nilai tukar yang dapat diperjualbelikan. Komodifikasi atas lahan menjadi sumber utama dari berjalannya proyek MIFEE yang berorientasi pada ekspor. Dengan cara pandang lahan sebagai komoditas, Merauke dianggap memiliki "idle land" (Ito, Savitri, dan Rachman, 2014) atau lahan yang menganggur. Meski telah diolah oleh masyarakat adat Marind-anim, lahan ini dianggap belum digarap dan memiliki potensi untuk dikonversi menjadi persawahan dan pertanian. Lahan tersebut dianggap "belum digarap" dan dikategorikan "menganggur" karena diukur berdasarkan ada atau tidaknya intervensi kapital atasnya: ia menganggur karena belum adanya upaya untuk mengomodifikasinya menjadi komoditas. Cara pandang ini diamini tidak hanya oleh pemerintah lokal dan nasional, tetapi juga oleh para investor yang terlibat serta masyarakat Papua yang merupakan penduduk migran dari Jawa dan Sulawesi. Pada akhirnya, hal ini menciptakan konflik horizontal antara orang-orang 
asli Papua dengan penduduk migran yang memiliki persepsi berbeda terkait lahan.

Dengan rencana penggarapan 1,2 juta hektar lahan, pemerintah berupaya menjadikan Merauke sebagai "Lumbung Pangan Nasional" yang memasok stok pangan tidak hanya bagi Indonesia, tetapi juga bagi dunia. Stok pangan yang dimaksud memberikan privilese bagi komoditas beras-dengan jargon "beras sebagai tulang punggung", Indonesia diharapkan dapat menjadi "pabrik" yang menghasilkan beras secara masif, baik secara luasan proyek maupun skala produksi. Selain beras, pemerintah juga memberikan ruang yang besar bagi komoditas dan pengolahan kayu, serta perkebunan kelapa sawit, tebu, dan jagung.

Komodifikasi atas lahan menjelaskan keuntungan yang berusaha didapatkan pemerintah pusat dan lokal dari proyek MIFEE. Keuntungan ini diukur dalam skala pertumbuhan ekonomi nasional. Sebagai komoditas, hasil ekspor pangan dari MIFEE kemudian ditujukan untuk akumulasi profit atau untuk membangun daerah-daerah lain di Indonesia. Merauke dipahami secara eksternal dan relasional-tidak sebagai satu kesatuan metabolisme yang utuh, tetapi melalui posisinya dalam dan kontribusinya bagi Indonesia dan dunia. Keberhasilan proyek MIFEE dilihat dari kontribusinya bagi PDB Provinsi Papua, dan seberapa bernilainya beras sebagai produk unggulan Merauke dibanding dengan daerah-daerah lain. Lahan di Merauke kemudian diekspektasikan dapat memenuhi permintaan atas beras di Indonesia dan untuk mewujudkan keamanan pangan nasional. Selain bertujuan menghasilkan tambahan cadangan pangan, MIFEE juga ditujukan untuk menghemat devisa negara karena jumlah impor yang berkurang.

Pemahaman atas lahan sebagai sebuah komoditas juga menciptakan batas-batas terkait aktor yang dianggap relevan dan tidak relevan untuk mencapai tujuan MIFEE. Dengan upaya komodifikasi, pemerintah mengandalkan sektor swasta dan investasi asing dalam melakukan 
penetrasi kapital dan mempekerjakan buruh untuk menggarap lahan di Merauke. Karenanya, keberhasilan MIFEE sangat ditentukan oleh investasi tersebut (Dewi, 2018). Menciptakan lingkungan yang kondusif bagi investasi serta melakukan deregulasi dan debirokratisasi atas peraturan yang menghambat investasi menjadi kunci penting untuk mengundang sebanyak-banyaknya investor dan mencapai target produktivitas MIFEE. Investasi asing ini juga menjadi pertanda terjadinya rescaling ruang dan kekuasaan dalam proyek MIFEE: MIFEE bukan sekadar isu yang dimiliki oleh Papua-ia, di saat bersamaan, adalah isu lokal, nasional, dan global. Internasionalisasi yang masif melalui berbagai investasi asing mengintegrasikan kepentingan dan cara pandang dari aktor-aktor di berbagai level terkait fungsi dan status lahan di Merauke.

Pada titik terjauhnya, keuntungan yang ingin didapatkan oleh pemerintah lokal dan pusat dari MIFEE mencakup upaya untuk mengonsolidasikan negara yang menampakkan diri sebagai entitas yang utuh dan berperan signifikan dalam menjaga kesatuan, keamanan, dan kesejahteraan nasional. Mendorong pertumbuhan dan pembangunan nasional menjadi narasi yang mendominasi peran ideal dari "negara" yang merupakan produk dari kontestasi politik antara berbagai kekuatan sosial dari waktu ke waktu. Pada titik ini, keberhasilan negara dalam mengontrol sumber daya dalam MIFEE menunjukkan upaya dan kekuasaannya untuk hadir mengatur daerah yang dianggap "pinggiran" dan sangat terlokalisasi. Hal ini juga memengaruhi legitimasi yang didapatkan negara di level nasional. Pada titik ini, retorika Joko Widodo "Membangun dari Pinggiran" juga perlu dikritisi, karena arah pembangunan yang didesain oleh pemerintah dan yang diharapkan oleh masyarakat lokal di Merauke bisa jadi berbeda.

Kedua, bagi masyarakat adat yang ada di Merauke-terutama suku Marind-anim-lahan dipahami sebagai sumber penghidupan, identitas, dan kemandirian. Karenanya, penggarapan atas lahan dilakukan 
untuk memenuhi kebutuhan pangan mereka sendiri, sebagai sumber subsistensi produksi dan hidup (Wharton, 1963). Lahan menjadi bagian dari perkembangan masyarakat adat yang penggunaannya sudah terbentuk secara historis. Tanah Ulayat adalah tempat masyarakat adat terutama menanam sagu sebagai makanan sehari-hari mereka-sebuah komoditas yang tidak masuk dalam prioritas MIFEE. Hutan juga adalah arena sebagai tempat masyarakat Papua berburu untuk memenuhi kebutuhan pangan sehari-hari. Dengan tujuan tersebut, masyarakat adat bergantung pada corak pertanian yang sederhana. Petani-petani lokal memiliki kemandirian di atas lahannya sendiri dengan bergantung pada corak produksi yang mereka kuasai dengan baik sebagai hasil dari transfer pengetahuan antargenerasi. Bersama alam, masyarakat adat mencapai keseimbangan kosmik dan mempertahankan relasi sosial-religius yang lekat dengan lahan tempat mereka tinggal. Dalam arti lain, lahan tidak hanya dimaknai sebagai sumber daya untuk bertahan hidup, tetapi telah terintegrasi dalam identitas masyarakat lokal. Masyarakat yang tumbuh dan berkembang bersama lahan menjadikan lahan sebagai bagian tidak terpisahkan dari pembentukan imajinasi atas dirinya serta kemandirian yang dimiliki sebagai seorang manusia. Dengan cara pandang tersebut, lahansebagai sumber dari subsistensi dan identitas-dianggap sebagai hak yang harus diberikan kepada masyarakat adat. Cara pandang ini juga didukung oleh berbagai gerakan masyarakat sipil di level nasional dan internasional yang mempromosikan narasi hak asasi manusia, demokratisasi, dan pengakuan hak-hak adat bagi masyarakat Papua.

Karenanya, keuntungan yang berusaha didapatkan dan dipertahankan oleh masyarakat adat lokal dari lahan mereka adalah (1) sumber pangan dengan jumlah yang cukup dan dengan jenis yang sesuai dengan kehidupan sehari-hari mereka, (2) identitas dan kemandirian diri, serta (3) relasi sosial yang terus dijaga dari generasi ke generasi. Upaya ini sangat dipengaruhi oleh sejarah konflik antara 
masyarakat di Papua-yang sering dianggap sebagai "warga negara kelas dua"-dengan pemerintah pusat sejak era Orde Baru. Kehendak atas kemandirian dan perjuangan akan identitas yang diasosiasikan dengan lahan menjadi begitu kuat karena pengalaman historis atas eksklusi dan invasi yang dianggap terus dilakukan oleh pemerintah Indonesia pada Papua. Karenanya, bagi masyarakat lokal, MIFEE hanya satu dari berbagai bentuk upaya pemerintah pusat untuk mengeksploitasi masyarakat dan sumber daya di Papua. Tidak hanya menghilangkan sumber penghasilan mereka, MIFEE juga mengubah identitas, kultur, dan bagaimana masyarakat adat lokal mendefinisikan dirinya sendiri dan posisinya sebagai warga negara Indonesia. Lebih jauh, perspektif masyarakat terhadap lahan dalam MIFEE merepresentasikan apa yang disebut Polanyi (1944) sebagai komoditas fiktif-tanah beserta kerja dari manusia tidak dapat dikomodifikasi secara utuh karena ia berakar pada relasi sosial masyarakat.

Meski berupaya mendapatkan akses pada satu bidang lahan yang sama, aktor akan bergerak untuk tujuan penggunaan yang berbeda atas lahan tersebut. Konflik kemudian terjadi karena ada perbedaan tujuan penggunaan lahan yang dimiliki para aktor, terutama karena pencapaian keuntungan bagi satu aktor akan menciptakan kerugian bagi aktor lainnya. Lebih jauh, cara aktor memosisikan lahan beserta keuntungan darinya dapat dipahami sebagai bagian atau refleksi dari cara pandang mereka atas bentuk pembangunan yang dianggap ideal. Hal ini dibahas tersendiri dalam subbagian selanjutnya.

\section{MEKANISME AKSES DALAM MIFEE: HEGEMONI MODERNISASI DAN PEMBANGUNAN BERCORAK JAWA-SENTRIS}

Bagian ini menjelaskan konfigurasi dari cara, proses, dan relasi yang memungkinkan aktor mendapatkan atau tidak mendapatkan 
keuntungan dari MIFEE. Konfigurasi tersebut menjadi prakondisi bagi akses yang dimiliki aktor: upaya untuk mengubah relasi akses, pada titik terjauhnya, harus mengintervensi prakondisi tersebut. Karenanya, dimensi struktural dan relasional dari MIFEE yang berimplikasi pada distribusi akses bagi para aktor dijelaskan dalam pembahasan di sini. Aspek-aspek tersebut merupakan konfigurasi dari akses terhadap kapital, pengetahuan, pasar, buruh, teknologi, otoritas, serta identitas sosial yang kemudian dijelaskan secara bersamaan.

Secara garis besar, cara pandang terhadap MIFEE berangkat dari asumsi yang spesifik terkait (1) model pembangunan yang dianggap ideal dan posisi Papua dalam sejarah pembangunan Indonesia dan (2) persepsi terhadap krisis pangan dan energi global. Dua cara pandang ini menciptakan batas-batas terkait pengetahuan, aktor, teknologi, dan identitas yang dianggap berkontribusi bagi MIFEE dan membentuk akses aktor terhadap sumber daya di Merauke.

Pertama, cara pandang terkait model pembangunan yang ideal pada dasarnya merepresentasikan debat antara pembangunan linear ala modernisasi dan alternatif atasnya, yang telah lama mencirikan kajian-kajian terkait pembangunan (lihat Escobar, 1995). Bagi aktoraktor yang mendorong MIFEE, pembangunan secara garis besar dipahami dalam kerangka neoliberalisme dan pertumbuhan ala Jawa. Pemerintah menganggap bentuk pertumbuhan tersebut sebagai model paling tepat untuk memajukan masyarakat lokal dan menjadi katalisator pembangunan di Merauke. Modernisasi dan industrialisasi menjadi kunci utama. Sebagai proyek industrialisasi skala besar, MIFEE mengharuskan adanya partisipasi dari modal asing dan penetrasi teknologi pertanian yang mutakhir, serta ilmu pengetahuan asing dan para ahli untuk memaksimalkan produktivitasnya-seluruh modal yang tidak dapat diakses oleh masyarakat lokal. 
Lebih jauh, diharapkan MIFEE dapat mewujudkan pemerataan pembangunan bagi masyarakat Merauke dengan trickle down effect (Wijanarko, 2017) dan pendekatan top-down yang sangat kuat. Cara pandang ini disokong oleh diskursus yang mengasumsikan bahwa orang-orang asli Papua "terbelakang, bodoh, dan agresif" (Lamonge, 2012). Hal ini menjadi sumber masalah yang membuat pertumbuhan di Merauke sangat lambat. Papua tidak dapat tumbuh karena ia tidak cukup modern dan tidak cukup kompetitif jika dibandingkan dengan daerah-daerah lain. Adanya ketimpangan disebabkan oleh lemahnya kualitas sumber daya manusia di Papua atau karena budaya-budaya lokal yang irasional dan menghambat mereka untuk tumbuh. Solusi yang ditawarkan kemudian adalah pelatihan, edukasi, atau peningkatan kesadaran masyarakat akan pertumbuhan ekonomi dan modernisasi, atau pemberian sanksi bagi yang melanggar (lih. IrbaDjaja, Purwanto, dan Sunoko, 2018).

Oleh karena itu, Papua dapat berkembang jika ia berhasil menjadi modern dan menyokong terciptanya formasi masyarakat dan corak produksi kapitalistik. Komodifikasi dan privatisasi dari lahan-lahan adat wajib dilakukan-kepemilikan lahan komunal yang diwarisi secara turun-temurun harus dikonversi ke hak milik pribadi yang dilindungi negara dan dapat disewakan, corak produksi tradisional berskala kecil harus diubah menjadi industrialisasi skala besar, dan komodifikasi dari buruh harus dilakukan untuk memproduksi komoditas. Karenanya, MIFEE berupaya memberikan kesempatan kerja dengan mengintegrasikan orang-orang Marind-Anim sebagai buruh yang dapat diupah rendah, meski upaya ini tidak selalu diikuti dengan ketertarikan masyarakat untuk bekerja dengan perusahaan (Zakaria et.al., 2011). Di saat yang sama, produksi pangan dari MIFEE kemudian diekspor ke pasar nasional dan internasional demi mengatasi krisis pangan dan energi global. Akses terhadap pasar berskala besar menjadi suatu privilese yang hanya dimiliki sebagian aktor dengan 
jejaring kapital berskala global, seperti investor-investor asing yang diberikan izin oleh negara. Beberapa di antaranya Medco Group, Wilmar, dan LG International (Dewi, 2018).

Akibat 32 tahun rezim Orde Baru, pembangunan yang berorientasi pada Jawa masih menjadi corak dari pembangunan di daerah pinggiran, tidak terkecuali di Papua. Pemerintah Soeharto yang disokong oleh militer cenderung mengakomodasi dan memberikan privilese bagi kepentingan dan model pembangunan masyarakat Jawa yang menghasilkan ketimpangan antara pusat dan pinggiran. Jawasentris tidak hanya berarti pertumbuhan tersebut ditujukan untuk memajukan Jawa sebagai pusat-seperti yang secara eksplisit terjadi di era sentralistik Soeharto-tetapi juga upaya untuk melakukan homogenisasi seluruh model pertumbuhan menjadi ala Jawa. Standardisasi pertanian disamaratakan seperti Jawa, pola pertanian ladang berpindah yang dilakukan oleh orang-orang Marind-Anim harus diubah menjadi pola pertanian sawah ala pertanian Jawa; sagu harus digantikan dengan nasi. Lebih jauh, keberhasilan dan pencapaian pembangunan akan diukur sesuai dengan kriteria yang bias Jawa. Karenanya, sejak transmigrasi yang masif dari Jawa dan Sulawesi Selatan di tahun 1970an, rancangan penanaman padi dilakukan dan urbanisasi terjadi di berbagai daerah di Papua. Pada titik ini, MIFEE hanya representasi satu dari sekian banyak kebijakan pemerintah pusat yang menggunakan Jawa sebagai patokan.

Dalam formasi masyarakat kapitalistik dan Jawa-sentris, Merauke dan Papua dianggap bernilai sejauh ia dapat berkontribusi bagi upaya kapitalisme mengatasi krisis over-akumulasinya, akibat daerah-daerah lain di Indonesia (terutama Jawa)—dan di belahan dunia lain-yang sudah jenuh atas kapital. Krisis tersebut mengharuskan kapitalisme melakukan ekspansi dan spatial fix (Harvey, 2001) ke daerah baru yang belum tersentuh kapital sama sekali untuk kembali menghasilkan 
profit. Proses ini menjadi sumber dari ketimpangan pembangunan di antara daerah-daerah yang terhubung dalam sirkuit kapital global.

Pada titik tersebut, Merauke menjadi lokasi di pinggiran yang tepat karena ia belum diintervensi oleh industrialisasi pertanian dan memungkinkan kapital untuk bekerja kembali. Produksi ruang atas lahan di Merauke kemudian terjadi, lahan dimaknai sebagai sumber daya potensial yang menganggur dan dapat dikomodifikasi untuk kepentingan negara dan investor. Pemaknaan masyarakat terkait lahan sebagai sumber penghidupan dan identitas terpinggirkan karena minimnya akses masyarakat bukan hanya pada lahannya, namun juga pada pengetahuan, kapital, dan otoritas sebagai prakondisi bagi akses tersebut.

Kedua, MIFEE disokong oleh narasi terkait krisis pangan dan energi yang melanda dunia sekitar tahun 2008. Pemerintahan Yudhoyono mempromosikan MIFEE sebagai program investasi agrobisnis berskala besar yang dapat mengubah krisis tersebut menjadi kesempatan, tidak hanya bagi Indonesia tetapi juga bagi dunia. Dalam arti lain, MIFEE dianggap sebagai solusi atas krisis global yang dianggap genting dan mendesak untuk diatasi, dengan cara dan metode apa pun yang memungkinkan. Mengatasi krisis pada momen tersebut dianggap sebagai "kepentingan umum" yang harus diprioritaskan. Diskursus ini membuat desain MIFEE beserta perampasan lahannya diterima secara sosial (Ito, Savitri, dan Rachman, 2014).

Alih-alih muncul sebagai narasi yang berkonotasi negatif, brutal, atau melemahkan, MIFEE sebagai solusi muncul dengan basis rasionalitas-ia memberikan imajinasi serta visi masa depan yang disepakati dan dianggap masuk akal bagi berbagai aktor. Pada titik terjauhnya, mendukung MIFEE dianggap sebagai bagian dari pengukuhan identitas subjek sebagai warga negara Indonesia dan global. Para aktor mendorong MIFEE sebagai upaya untuk berkontribusi bagi 
krisis yang melanda dunia dan sebagai bentuk proyeksi atas peran dirinya di tengah masyarakat.

Sebagai bagian dari proyek nasional, MIFEE juga disokong secara legal oleh berbagai regulasi dan grand design yang dikeluarkan oleh pemerintah pusat dan didukung oleh pemerintah lokal. MIFEE merupakan salah satu dari enam target koridor ekonomi dalam Masterplan Percepatan dan Perluasan Pembangunan Ekonomi Indonesia (MP3EI) 2011-2025 yang didesain sebagai pusat pengembangan pangan, perikanan, energi, dan pertambangan nasional. MP3EI memuluskan masuknya investasi asing karena mendesain kontribusi pemerintah hanya sekitar $10 \%$ dari total biaya dan diwujudkan via penyediaan infrastruktur dasar. Sisanya kemudian disediakan oleh sektor swasta, BUMN, atau melalui mekanisme Public Private Partnership. MP3EI juga melembagakan tingkat investasi yang rendah di Papua sebagai sumber permasalahan pembangunan di Papua. Di sisi lain, Peraturan Presiden No. 66/2011 tentang Pembentukan Unit Percepatan Pembangunan Provinsi Papua dan Provinsi Papua Barat (UP4B) juga memberikan legitimasi bagi intervensi pemerintah untuk memastikan segala hambatan politik dan penegakan hukum dalam MIFEE dapat teratasi dengan baik.

UU No. 21/2001 tentang Otonomi Khusus bagi Provinsi Papua juga menjadi peraturan yang memungkinkan MIFEE untuk berjalan dan melakukan marginalisasi terhadap masyarakat adat lokal. Dengan adanya otoritas tersebut, pemerintah Kabupaten Merauke dapat memberikan izin lokasi untuk konsesi pada perusahaan-perusahaan tanpa adanya persetujuan dari masyarakat lokal. Hal tersebut gagal untuk melindungi hak atas tanah Ulayat dari masyarakat adat. Di saat yang sama, meski hak masyarakat adat sudah tercantum dalam konstitusi dan UU Pokok Agraria 1960, pasal-pasalnya sering kali dianggap ambigu dan mengundang berbagai interpretasi dalam implementasinya sehingga merugikan masyarakat (Lamonge, 2012). 
Pengakuan tanah adat yang diberikan pemerintah, beserta konversi lahan komunal adat menjadi hak milik di bawah negara, justru memudahkan perusahaan untuk menyewa lahan-lahan tersebut dan mendapatkan akses atasnya demi menjalankan proyek MIFEE. Sebagai konsekuensi dari pelembagaan tersebut, MIFEE juga disokong dan diamankan oleh aparat militer (Zakaria et.al., 2011) yang bertujuan menjaga stabilitas kawasan dan memastikan tidak ada gangguan bagi berjalannya proyek MIFEE.

Lebih jauh, Kebijakan Satu Peta Nasional yang diperkenalkan Yudhoyono pada tahun 2010 dan dilanjutkan oleh Widodo juga berupaya menciptakan peta tematik atas perencanaan spasial yang terintegrasi di level nasional dan digunakan untuk memudahkan pengeluaran izin investasi (Dewi, 2018). Hal ini berdampak pada definisi dan peruntukan lahan yang diberikan pada Papua dan Merauke, serta menyediakan perencanaan spasial baru bagi MIFEE.

Mekanisme akses di atas bekerja secara bersamaan dan saling mendukung dalam proyek MIFEE. Mekanisme tersebut adalah produk dari selektivitas strategis negara. Ia muncul sebagai sebuah konfigurasi struktural yang mengondisikan dan membatasi pilihanpilihan aktor di dalamnya serta memungkinkan sebagian aktor dengan mudah mendapatkan akses atas lahan di Merauke sedangkan yang lainnya tidak. Secara umum, yang mendapatkan akses atas lahan dan keuntungan yang besar pada proyek MIFEE adalah para investor dan pemerintah. Hal ini terjadi karena aktor-aktor tersebut-dengan segala aksesnya terhadap berbagai bentuk kapital materiil dan immaterialdapat mengkooptasi lahan dengan hak milik masyarakat adat menjadi sumber profit dan domain beroperasinya kekuasaan negara yang koersif. 


\section{RELASI KUASA DAN PERJUANGAN “MEREBUT” NEGARA DALAM AKSES ATAS LAHAN: RESTRUKTURISASI KEKUASAAN ORDE BARU DALAM MIFEE}

Bagian ini membahas relasi kuasa yang bekerja di balik mekanisme akses dalam MIFEE. Secara garis besar, relasi kuasa ini bersifat kontinjen meski ia dibentuk oleh struktur kekuasaan dan selektivitas strategis negara yang telah terkondensasi secara temporal. Kekuatan aktor dalam relasi tersebut bergantung pada posisinya yang berubahubah dalam struktur ekonomi-politik yang lebih luas, baik di level lokal, nasional, maupun global.

Relasi kuasa yang bekerja dalam MIFEE tidak bisa dilepaskan dari dinamika operasi kekuasaan di era Pasca Kemerdekaan dan Orde Baru yang memberikan atau tidak memberikan privilese bagi posisi aktor tertentu dalam struktur ekonomi-politik di Indonesia. Pembangunan di Papua dan mega proyek di dalamnya memiliki sejarah panjang yang tidak bisa diisolasi hanya pada MIFEE. Isu nation-building, perjuangan identitas, dan kehendak untuk menentukan nasib sendiri menjadi tiga aspek penting yang membentuk relasi kuasa antara aktor-aktor lokal dan nasional sejak periode dekolonialisasi Indonesia. Sebagai negara yang baru saja merdeka, Indonesia perlu menjaga stabilitas, keamanan, dan keutuhan dirinya dengan mengintegrasikan Papua untuk memutus sepenuhnya pengaruh Belanda.

Penggunaan kekerasan militer untuk memaksa orang-orang asli Papua agar memilih bergabung dengan Indonesia di 1969 menjadi sesuatu hal yang membuat masyarakat Papua kian mempertanyakan posisi mereka sebagai warga negara Indonesia dari waktu ke waktu (Lamonge, 2012). Pembagian strata kelas sejak era Kolonialisme Belanda yang membagi masyarakat menjadi tiga secara hierarkis-orang Belanda kulit putih, orang Indonesia-Jawa/Arab, dan orang berkulit 
hitam seperti Papua—membuat masyarakat Papua berada dalam rantai paling bawah dalam struktur kekuasaan. Hal tersebut juga membuat mereka menggunakan terminologi seperti "Indonesianisasi" untuk menjelaskan pembangunan teknokratik yang dibawa oleh pemerintah pusat kepada lahan, budaya, dan kehidupan sosial-ekonomi mereka.

Pembangunan Papua sejak era Orde Baru sering kali merefleksikan fantasi pembangunan di pusat-eksploitasi atas sumber daya dan masyarakat Papua telah menjadi sebuah fitur yang konsisten dalam intervensi pemerintah terhadap Papua. Marginalisasi terhadap orang asli Papua yang dianggap warga negara sekunder, proyek top-down, serta ancaman penggunaan kekerasan menjadi sesuatu yang lumrah dilakukan. Hal tersebut memperparah trauma psikologis yang dialami masyarakat Papua dari represi dan eksklusi berkepanjangan dalam kehidupan sosial, politik, dan ekonomi di era Orde Baru (Lamonge, 2012). Intervensi pemerintah pusat di masa lampau - dengan pendekatan Jawa-sentrisnya-menjadi latar belakang yang mengerangkai relasi konfliktual antara masyarakat Papua dan pusat sampai hari ini. Perjuangan atas identitas dan wilayah tetap menjadi akar dari relasi yang dinamis antara keduanya. Karenanya, distribusi akses yang tidak merata dalam MIFEE adalah produk historis dan representasi struktur kekuasaan di level nasional yang sudah mengkristal sejak lama.

Hal ini dapat dilihat salah satunya dari perusahaan-perusahaan agrobisnis dan konglomerat yang terlibat dalam MIFEE. Kertas Nusantara milik Prabowo Subianto, Artha Graha milik Tommy Winata, dan PT. Bangun Cipta Sarana yang terhubung dengan salah satu menteri di era Soeharto merupakan beberapa perusahaan-perusahaan kroni Soeharto yang mendapatkan keuntungan melimpah di bawah era Orde Baru dan memiliki keterlibatan dalam berbagai proyek di Papua, termasuk MIFEE (Ginting dan Pye, 2013). 
Di sisi lain, desentralisasi yang berupaya untuk menghapus corak kekuasaan sentralistis ala Soeharto tidak berjalan dengan baik. Alih-alih mewujudkan pemerataan bagi daerah-daerah di pinggiran, desentralisasi dikooptasi oleh berbagai kepentingan ekonomi-politik para aktor di era Soeharto yang menciptakan jejaring patronase dan oligarki-oligarki baru di level lokal (Hafidz, 2004). Dengan adanya restrukturisasi kepentingan aktor-aktor lama, desentralisasi kemudian menciptakan konflik dan kompetisi politik baru di antara aktor atau pemerintah lokal-baik antara Bupati dan Gubernur, atau antara dinas dengan berbagai kewenangannya-untuk mendapatkan kontrol terhadap otoritas dan sumber daya di daerah yang diperparah oleh korupsi.

Di Papua, hal tersebut salah satunya terlihat dari konflik antara Bupati Merauke dan Gubernur Papua terkait luasan lahan MIFEE. Konflik tersebut menunjukkan bahwa desentralisasi hanya menggeser level konflik antar-elit yang terjadi tanpa memberikan pengaruh signifikan bagi posisi masyarakat. Masyarakat tetap menduduki posisi marginal dalam struktur ekonomi politik status quo yang terus direproduksi. Dengan adanya relasi kuasa yang menetap dan dipertahankan sedemikian rupa dalam oligarki, posisi aktor-aktor dalam konflik MIFEE cenderung sama untuk jangka waktu tertentu.

Relasi kuasa tersebut merupakan konteks yang kemudian membuat kelompok-kelompok sosial spesifik (pemerintah lokal dan pusat serta para investor yang ada dalam lingkaran oligarki) mampu "merebut" atau memberi karakter pada negara yang ideal, termasuk mendefinisikan posisi ontologis negara beserta dengan arah kewenangan yang "seharusnya" dilakukan oleh negara. Pada titik ini, negara memiliki logikanya tersendiri meski merupakan produk dari kontestasi. Hal ini membantah tesis neoliberalisme dalam MIFEE (Lamonge, 2012) yang menyatakan bahwa peran negara dibatasi pada penyediaan infrastruktur di daerah dan memfasilitasi para investor 
melalui "fleksibilitas" dalam peraturan, perpajakan, dan penggunaan aparat militer ketika dibutuhkan demi mengundang banyak investasi.

Upaya-upaya untuk hadir di Merauke melalui serangkai kepengaturan dan kewenangan menggunakan aparatus koersif menjadi cara negara mengonsolidasi kekuasaannya, terutama dalam konteks historis upaya nation-building Indonesia dan meredam gerakangerakan separatis di Papua untuk menjaga keutuhan Indonesia sebagai suatu kesatuan negara-bangsa. Akumulasi kapital menjadi salah satu strategi yang juga dimungkinkan oleh negara karena, berbeda dengan akumulasi kapital jangka pendek dari kapitalisme, kebutuhan akumulasi yang sama melekat pada struktur negara yang perlu mempertahankan dirinya untuk jangka waktu yang sangat panjang.

Relasi kuasa dan selektivitas strategis negara yang bekerja tidak memungkinkan adanya mekanisme akses yang membuat masyarakat asli Papua mendapatkan keuntungan besar dari proyek MIFEE. Diskursus yang dibawa oleh masyarakat sulit untuk mendapatkan posisi signifikan karena karakter pembangunan di Indonesia yang bias Jawa, jika ditarik jauh ke sejarah pembangunan Papua sejak era Orde Baru. Meski demikian, relasi kuasa yang timpang tersebut bukan sesuatu yang datang begitu saja dan bertahan tanpa adanya manuvermanuver politik. Sebagai produk dari manuver politik, relasi kuasa tersebut pada dasarnya sangat rentan untuk berubah.

Dalam kondisi demikian, masyarakat adat Papua memahami posisi mereka dalam struktur kekuasaan MIFEE yang menghambat akses mereka pada lahan. Mereka secara aktif dan strategis menampilkan dan menghidupi "identitas" yang berbeda-beda dalam waktu yang bersamaan. Pada satu kesempatan, mereka menampilkan diri dan berbicara sebagai masyarakat adat Papua yang dapat mengklaim tanah Ulayat mereka. Di kesempatan lain yang lebih konfrontatif, seperti dalam demonstrasi-demonstrasi, mereka menampilkan diri 
sebagai warga negara Indonesia: mereka menggunakan terminologiterminologi dalam konseptualisasi kewargaan tersebut dan dengan yakin menunjukkan hak-hak mereka yang seharusnya dilindungi oleh konstitusi. Karenanya, mereka dengan sigap meningkatkan kapasitas dan pemahaman mereka terkait bagaimana struktur negara-bangsa atau negara hukum itu bekerja. Hal ini dilakukan agar mereka dapat menggunakan bahasa yang diakui, dipahami, dan dapat "dibaca" dalam sistem tersebut, dan agar upaya mereka memperjuangkan akses dapat dianggap relevan.

Upaya-upaya tersebut berjalan melalui inisiasi mereka dalam membentuk berbagai gerakan dan koalisi untuk menentang ataupun "mengakali" dan mengapropriasi sistem dominan yang bekerja. Koalisi Masyarakat Sipil Tolak MIFEE dengan Forum Kerja Sama Lembaga Swadaya Masyarakat Papua (Foker LSM Papua) dan Dewan Adat Papua menjadi kunci dari upaya ini. Organisasi gereja, organisasi mahasiswa, organisasi masyarakat sipil, dan NGO, baik di level nasional dan internasional, seperti Aliansi Masyarakat Adat Nusantara (AMAN), Wahana Lingkungan Hidup Indonesia (WALHI), Jaringan Advokasi Tambang (JATAM), Greenpeace Indonesia, serta lembaga think tank seperti Pusaka dan Sawit Watch juga terlibat aktif dalam jejaring aliansi tersebut.

Melalui aliansi tersebut, masyarakat berupaya melakukan pemetaan partisipatoris terhadap batas-batas dan peruntukan wilayah mereka. Mereka juga menyediakan bantuan legal, rangkaian konsultasi publik, serta pelatihan bagi masyarakat adat Papua untuk memastikan, di samping upaya penolakan yang dilakukan, mereka tetap dapat mendapatkan keuntungan dari struktur yang ada (Zakaria et.al., 2011). Koalisi tersebut adalah ruang bagi para aktor dan masyarakat lokal bertukar informasi dan pengetahuan terkait MIFEE, serta secara aktif mengembangkan analisis spasial atas dampak yang kemungkinan mereka rasakan dari implementasi MIFEE. 
Dengan pengenalan terhadap prinsip Free and Prior Informed Consent, mereka berupaya memahami cara proyek MIFEE bekerjamereka meningkatkan kapasitas dan pemahaman diri mereka dalam struktur relasi kekuasaan yang ada dan terkait hak-hak mereka sebagai masyarakat adat dan warga negara Indonesia. Mereka berupaya mengajukan kepemilikan mereka terhadap lahan adat berbasis marga yang dimiliki oleh berbagai klan lokal-Balagaise, Basik-Basik, Gebze, Kaize, Mahuze, Samkakai (Zakaria et.al., 2011). Meski kepemilikan lahan mereka telah ditarik menjadi milik negara atau melalui hak milik individu, keberadaan lahan adat berbasis marga ini menjadi hambatan yang besar bagi MIFEE.

Dengan kapasitas dan pengetahuan mereka terkait proyek MIFEE dan bagaimana sistem hukum dalam negara modern bekerja, mereka dapat menyiasati berbagai upaya dari perusahaan-perusahaan untuk mendapatkan izin hak guna mengembangkan perkebunan di lahanlahan mereka. Meski dijanjikan pembangunan infrastruktur dan kualitas sumber daya manusia-jalan, sekolah, kesempatan kerjamasyarakat adat dapat memahami dampak negatif dan konflik yang mungkin muncul dari persetujuan mereka terhadap tawaran-tawaran tersebut. Dengan selektif dan rasional, mereka kemudian melakukan penolakan.

Berbagai upaya oposisi dan apropriasi yang mereka lakukanmeski belum dapat sepenuhnya mengubah relasi kekuasaan dalam struktur ekonomi-politik yang lebih besar-pada akhirnya berhasil menunjukkan upaya mereka untuk "merebut" dan mendefinisikan negara, terutama dalam perspektif hak. Gerakan-gerakan tersebut meredam maraknya euforia investor-investor potensial untuk mengimplementasikan penetrasi kapital di Merauke. Hal ini juga mengubah atmosfer politik di Merauke sendiri menjadi lebih kondusif bagi masyarakat adat untuk mempertahankan aksesnya atas lahan (Ginting dan Pye, 2013). Akhirnya, hanya 10 dari 46 perusahaan yang 
mendapatkan izin beroperasi aktif untuk mengembangkan perkebunan mereka di Merauke pada 2012 (Aliansi Demokrasi untuk Papua, 2012).

Hal ini juga menunjukkan aspek relasional dari struktur kekuasaan yang bekerja dan agensi dari aktor-aktor di berbagai level—tidak hanya masyarakat adat, tetapi juga investor dan pemerintah. Struktur yang ada dan sedikit banyak berubah karena adanya oposisi dari masyarakat adat mengharuskan investor dan pemerintah untuk menyesuaikan dan menyusun respons atau strategi baru, yang kemudian dapat kembali mengubah struktur tersebut. Hal tersebut akan berlangsung terusmenerus sehingga upaya untuk mendapatkan akses atas lahan dalam MIFEE merupakan sesuatu yang tidak pernah menetap dan bersifat relasional. Ia akan berubah sesuai dengan konfigurasi kekuasaan yang ada. Karenanya, diperlukan sensitif terhadap struktur selektivitas negara yang berubah-ubah dalam konteks spasial-temporal yang berbeda sebagai upaya untuk memperbesar akses atas lahan dalam MIFEE. Hal ini digunakan untuk menyusun ulang strategi para aktor dalam mengontrol dan mempertahankan aksesnya atas lahan.

\section{KESIMPULAN}

Tulisan ini menunjukkan bagaimana konflik dalam MIFEE merupakan kontestasi berbagai aktor dan kekuatan sosial untuk "merebut" atau mentransformasi struktur selektivitas strategis negara agar dapat memungkinkan mereka mendapatkan akses atau aliran keuntungan dari MIFEE. Hal ini mudah dan sulit bagi berbagai aktor yang berbeda, karena berbagai strategi yang mereka lakukan akan dipengaruhi oleh struktur selektivitas strategis negara yang sudah terkondensasi dan mengondisikan pilihan-pilihan mereka. Berbagai aktor yang tidak diuntungkan dari privilese struktur negara harus bergerak dua kaki: mereka harus bekerja dengan logika negara agar strateginya dapat menjadi relevan dan "terbaca" oleh sistem yang 
dominan, namun di saat yang sama juga harus mencari cara untuk mentransformasi struktur tersebut agar menguntungkan mereka. Posisi aktor-aktor akan berbeda sesuai struktur selektivitas tersebut. Namun, perbedaan itu juga menjadi peluang bagi mereka untuk mengubahnya.

Perlawanan bukan terjadi antara masyarakat versus negara, namun antara masyarakat versus pemerintah, bisnis, atau kelompok masyarakat lainnya dalam menyeimbangkan kekuatan dan membuat posisi tawarnya cukup setara. Hal ini juga menunjukkan bahwa perlawanan dilakukan oleh masyarakat adat bukan untuk membuat negara tidak relevan atau untuk menghilangkan negara dari kehidupan sosial, politik, budaya, dan ekonomi mereka: mereka justru berupaya untuk terlibat "dalam" negara dengan mengubah struktur selektivitasnya agar menguntungkan mereka. Mereka harus "mengintervensi" struktur negara tersebut agar konfigurasinya bisa membuat mereka mendapatkan dan mempertahankan akses keuntungan mereka dalam MIFEE. Dinamika relasional antara struktur selektivitas yang membatasi pilihan aktor serta upaya aktor untuk memanfaatkan atau mengubah struktur tersebut, akan terjadi terus-menerus dan tidak pernah selesai. Ia akan menjadi corak dalam konflik MIFEE. 


\section{REFERENSI}

Aliansi Demokrasi Untuk Papua. (2012). Janji Perusahaan Bangun Sarana Pendidikan Bohong. http://www.aldp-papua.com/?p=8009. Diakses 13 Maret 2020.

Dewi, R. (2016). Gaining Recognition Through Participatory Mapping? The Role of Adat Land in the Implementation of the Merauke Integrated Food and Energy Estate in Papua, Indonesiatudy: Implementation of Merauke Integrated Food and Energy Estate, Papua, Indonesia. Austrian Journal of South-East Asian Studies, 87-106 Pages. https://doi.org/10.14764/10. ASEAS-2016.1-6.

. (2018). Adat Recognition in Merauke Integrated Food and Energy Estate in Papua, Indonesia, Masyarakat Indonesia: Majalah Ilmu-Ilmu Sosial Indonesia, 44 (1), 121-136.

Giddens, A. (1984). The Constitution of Society: Outline of The Theory of Structuration. California: University of California Press.

Ginting, L. \& O. Pye. (2013). Resisting Agribusiness Development: The Merauke Integrated Food and Energy Estate in West Papua, Indonesia. ASEAS Austrian Journal of South-East Asian Studies, 6 (1), 160-182.

Hadiz, V. R. (2004). Decentralization and Democracy in Indonesia: A Critique of Neo- Institutionalist Perspectives. Development and Change, 35 (4), 697718. https://doi.org/10.1111/j.0012-155X.2004.00376.x.

Harvey, D. (2001). "Globalization and the "Spatial Fix" dalam Geographische Revue: Marxism in Geography.

Hay, C., Lister, M., \& D. Marsh. (2006). The State Theories and Issues. Palgrave Macmillan. $\quad$ http://search.ebscohost.com.uow.idm.oclc.org/login. aspx? direct $=$ true $\&$ scope $=$ site $\& d b=$ lebk $\& d b=$ labk\&AN $=197555$. 
IrbaDjaja, P. Purwanto., \& H. R. Sunoko(2018). The Analysis on Continous Development Strategy at Farming Production Centre of Mifee Program In Merauke Regency. E3S Web of Conferences, 73, 09020. https://doi. org/10.1051/e3sconf/20187309020.

Ito, T., Noer Fauzi Rachman, \& Laksmi A. Savitri. (2014). Power to Make Land Dispossession Acceptable: A policy Discourse Analysis of the Merauke Integrated Food and Energy Estate (MIFEE), Papua, Indonesia. The Journal of Peasant Studies, 41 (1), 29-50. https://doi.org/10.1080/030661 50.2013.873029.

Jessop, B. (1985). Nicos Poulantzas: Marxist Theory and Political Strategy. Basingstoke:Macmillan. . (1990). State Theory: Putting the Capitalist State in Its Place. Cambridge: Polity Press.

. (1999). The Strategic Selectivity of The State: Reflections on a Theme of Poulantzas, Journal of the Hellenic Diaspora, 25 (1-2), 1-37.

Jones, R. (2007). People/States/Territories: The Political Geographies of British State Transformation. Malden: Blackwell Pub.

Lamonge, M. (2012). Neo-liberalism, Social Conflict and Identity of Papuan Indigenous People: Case Study of Merauke Integrated Food \& Energy Estate (MIFEE) in Papua. A Research Paper in partialfulfilment of the requirements for obtaining the degree of Masters of Arts In Development Studies. https:// pdfs.semanticscholar.org/ 8ed9/ecc1e11bd2fd2fbbfacf918f1dc48d59adf0. pdf. Diakses 11 Maret 2020.

Mustika, E.T. (2014). “MIFEE: Blessing or Calamity?" Final Assignment of Challenges for Developing Countries Course, Department of International Program of International Relations, Faculty of Social and Political Science, University of Muhammadiyah Yogyakarta. 
Obidzinski, K., Ikuko Takahashi, Ahmad Dermawan, Heru Komarudin, \& Agus Andrianto. (2013). Can Large Scale Land Acquisition for AgroDevelopment in Indonesia be Managed Sustainably? Land Use Policy, 30 (1), 952-965. https://doi.org/10.1016/j.landusepol. 2012.06.018.

Pichler, M. (2015). Legal Dispossession: State Strategies and Selectivities in the Expansion of Indonesian Palm Oil and Agrofuel Production. Development and Change, 46 (3), 508-533.

Polanyi, K. (2001). The Great Transformation: The Political and Economic Origins of Our Time. 2nd Beacon Paperback ed. Boston, MA: Beacon Press.

Silubun, A. J. \& S. G. A. Putri(2019). Analysis of The Implementation Impact of Merauke Integrated Food and Energy Estate (MIFEE). IOP Conf. Series: Earth Environ. Sci. 235012086.

Suryani, D. (2016). Structural Violation of Indigenous Human Rights in Indonesia: A Case Study of Merauke Integrated Food and Energy Estate (MIFEE) in Papua. Jurnal Masyarakat \& Budaya, 18 (1): 97-108.

Wambrauw, E.V. \& Te Kipa Kepa Brian Morgan. (2017). The Sustainability of the Merauke Integrated Food and Energy Estate (MIFEE). The International Journal of Environmental Sustainability, 13 (2): 15-36.

Wharton, C.R. (1963). The Economic Meaning of 'Subsistence'. Malayan Economic Review, 8 (2).

Wijanarko. (2017). Transformasi Masyarakat Pedesaan dalam Program MIFEE (Merauke Integrated Food and Energy Estate) dalam Prosiding Seminar NasionalFHISIP-UT2017: Transformasi SosialMenuju Masyarakat Infromasi yang Beretika dan Demokratis', 249-267. http://digilib.mercubuana.ac.id/ manager/t!@file_artikel_abstrak/Isi_Artikel_23428232976 4.pdf. Diakses 11 Maret 2020. 
Zakaria, R. Y., Emilianus Ola Kleden\& Y. L. Franky. (2011). MIFEE: Tak Terjangkau Angan Malind-Catatan Atas Upaya Percepatan Pembangunan MIFEE di Kabupaten Merauke, Papua. Jakarta: Yayasan Pusaka. 